\title{
Tarihle Etkileşimi Bağlamında Ahlaki Bilincin Evrenselliği ve Tarihselliği Problemi
}

ŞengüI ÖZDEMIR*

The Problem of the Universality and Historicity of Moral Consciousness in the Context of its Interaction with History

Citation/C: Özdemir, Şengül, (2019). The Problem of the Universality and Historicity of Moral Consciousness in the Context of its Interaction with History, Milel ve Nihal, 16 (2), 331-349.

Abstract: In today's world, which is described as a global village, in which different styles of experience or discourses are often confronted surrounds people. This fact confronts human consciousness with the question of how to make sense of the moral. Because in the rapidly transforming global world, the common critical area for "the best" to discuss the moral dimension of the interpersonal relationship is gradually disappearing. In this article, the universal and historical perspective of moral consciousness is analyzed in opposite contexts such as cartesian and hermeneutics and how the "historical" dimension contributes to the development of the critical field of moral consciousness is examined. The aim of this analysis is to investigate how the meaning of the critical and free space of human relationships, which are increasingly isolated from each other in the global world, but more often exposed to each other, is understood. In this study, it is pointed out that, contrary to the notion of universality, hermeneutic thought sees the critical and free space of moral consciousness by considering the historical character of the present practical world. Therefore, it is stated that hermeneutic perspective, which develop comments by considering the existing experiences of people and the religious, traditional and cultural discourses that shape this experience, can contribute to the development of a moral consciousness which is constantly questioned and enriched on the "best" axis.

Keywords: Cartesian, Hermeneutics, Historicity, Universality, Moral Consciousness.

* Arş. Gör., Sinop Üniversitesi, İlahiyat Fakültesi, İslam Felsefesi Anabilim Dalı [sozdemir5561@hotmail.com] ORCID: 0000-0001-9921-0873. 
Atıf/C: Özdemir, Şengül, (2019). Tarihle Etkileşimi Bağlamında Ahlaki Bilincin Evrenselliği ve Tarihselliği Problemi, Milel ve Nihal, 16 (2), 331-349.

Öz: Küresel köy olarak nitelenen günümüzde farklı tecrübe tarzlarının veya söylemlerin çok sık şekilde yüzleşildiği bir dünya insanları kuşatmaktadır. $\mathrm{Bu}$ durum insan bilincinin ahlaki olanı nasıl anlamlandıracağı sorununu ortaya çıkarmaktadır. Zira hızla dönüşen küresel dünyada insanlar arası ilişkinin ahlaki boyutunu tartışabileceğimiz "en iyi"ye dair ortak eleştirel alan giderek kaybolmaktadır. Bu makalede ahlaki bilince dair evrensel ve tarihsel perspektif, kartezyen ve hermenötik gibi zıt bağlamlar içinde analiz edilmekte, "tarihi" boyutun ahlaki bilince dair eleştirel alanın oluşumuna nasıl katkı sunduğu irdelenmektedir. Bu analizin amacı küresel dünyada birbirinden gittikçe soyutlanan fakat birbirine daha sık maruz kalan insani ilişkilere dair eleştirel ve özgür alanın nasıl anlamlandırıldığını soruşturmaktır. Bu incelemede evrensellik düşüncesinin aksine hermenötik düşüncenin mevcut pratik dünyanın "tarihi" vasfını dikkate alarak ahlaki bilince dair eleştirel ve özgür alanı mümkün gördüğüne dikkat çekilmektedir. Dolayısıyla insanların mevcut tecrübelerini ve bu tecrübeye şekil veren dini, geleneksel, kültürel söylemlerini dikkate alarak yorum geliştiren hermenötik perspektifin, "en iyi" ekseninde sürekli şekilde sorgulanıp zenginleştirilen ahlaki bir bilincin geliştirilmesine katkıda bulunabileceği dile getirilmektedir.

Anahtar Kelimeler: Kartezyen, Hermenötik, Tarihsellik, Evrensellik, Ahlaki Bilinç.

\section{Giriş}

Bilim ve teknolojinin ilerlediği; ulaşım ve haberleşmenin çeşitli araçlar vasıtasıyla sürekli ve hızlı hale geldiği bir çağda gerçeklik (reality) kendisini çok farklı şekillerde insan bilincine dayatmaktadır. Bu durum öngörülemeyen hızda ve süreklilikte insanın değişimi tecrübe etmesine sebep olmaktadır. Söz konusu küresel çaptaki bu değişimler ahlaki bilince dair geleneksel söylem tarzlarının anlamını da sorgulanır hale getirmektedir. Zira bir paradoks olarak küreselleşme, bireyleri birbirinden soyutlayıp karşılıklı olarak kayıtsız ilişkiler şeklinde kendisini göstererek ${ }^{1}$ ahlaki bilince zemin teşkil eden ortak eleştirel alanı tahrip etmektedir. Bu sebeple geleneksel söylemler içinde ontolojik zeminde evrensel olarak temellendirilmeye çalışılan ahlaki bilincin anlamı, küresel dil içerisinde tarihsel bir algı

1 Augusto Ponzio, “Levinas'ın Batı Düşüncesinin İki Kalesi Hümanizm ve Kimlik Üzerine Eleştirisi", çev.: Hande Koçak, Monokl 4/VII-IX (Sonbahar 2010): 195. 
Tarihle Etkileşimi Bağlamında Ahlaki Bilincin Evrenselliŏgi ve Tarihselliọ̆i Problemi biçimi olarak konumlandırıldığı dile getirilmektedir. ${ }^{2}$ Nitekim "küresel köy" olarak nitelenen günümüz dünyasında farklı tecrübe tarzlarının veya söylemlerin çok sık şekilde yüzleştiği bir dünya insanları kuşatmaktadır. Bu tecrübe tarzı, insanı hem kendisiyle hem de diğer insanlarla ilişkisini -ahlaki olanı- nasıl anlamlandıracă̆ı sorunuyla yüzleştirmektedir. Böyle bir dünyada hangi tecrübenin ahlaken daha iyi, doğru ya da güzel olduğunu tartışmak giderek karmaşık hale gelmektedir. Başka bir ifadeyle bu çeşitlilik içinde "en iyi"ye dair anlam arayışı giderek silikleşmekte ve her insan kendi "iyi" sini kutsamakta ya da en azından onunla yaşamaya razı olarak birbirinden gittikçe soyutlanmaktadır. Böylesine hızla dönüşen dünyada tabiri caizse insanların çil yavrusu gibi dağılarak birbirinden soyutlanmasını önleyecek ve hala birbirleriyle daha iyi olanı arayış etrafında anlamlı bir ilişkiyi geliştirebilecek ahlaki bilinç nasıl mümkün olacaktır? İnsanların tüm farklılıklarına rağmen birbirleriyle baskı ve şiddet değil de "en iyi" yi arayış bağlamında buluşturabilecek bir ahlaki bilinç neyi talep etmektedir? İnsanların hem mevcut tecrübelerini ve bu tecrübeye şekil veren geleneksel söylemlerini hem de yüzleştikleri farklı tecrübeleri "en iyi" ekseninde zenginleştirecek ahlaki bilinç nasıl mümkün olacaktır?

Ahlaki bilincin odağında "en yüksek iyi" nin ne olduğu problemi bulunmaktadır. ${ }^{3}$ Mevcut tecrübeye dair "en yüksek iyi" ise "olan" ve "olmasi gereken" gibi farklı boyutlar ekseninde salınmaktadır. Bu salınımda ahlaki bilinç, tarihsellik ve evrensellik gibi farklı perspektifler bağlamında yorumlanmaktadır. Fakat anlamanın doğasından kaynaklanan bir durum olarak hem evrensellik hem de tarihsellik anlayışının tek bir görüş veya anlayışla ifade etmenin

2 Burhanettin Tatar, "Din ve Ahlak İlişkisi", İslâm Ahlâk Esasları ve Felsefesi El Kitabı, ed. Müfit Selim Saruhan (Ankara: Grafiker Yayınları, 2016), 18.

3 "Pek çok etikçi için bir "en yüksek iyi" (agathon, summum bonum) sayıltısına dayanmayan herhangi bir ahlaksal yaşam biçimi yoktur. Bu etikçilere göre özellikle günümüzde eylemlerini ve yaşam biçimlerini "iyi", "kötü" gibi değerlendirme ölçütlerine tabi tutmadan düzenlemek isteyen, hatta bu gibi değerlendirme ölçütlerini "aşılmış", "geride kalmış" sayarak aşağılayan insanların çoğalmasına rağmen, farkında olsunlar olmasınlar, bu insanlar da dahil olmak üzere , herkesin kendine göre benimsediği veya bir grup (parti, sendika, cemaat, gelenek) tarafından kendisine benimsetilmiş bir "iyi" yi gerçekleştirmeye çabaladıkları açıktır. ... insan yaşamının anlamı ve değeri, bazıları farkında olmasalar da herhangi bir "en yüksek iyi"yi gerçekleştirme ve ona ulaşma çabasında belirir." bk. Doğan Özlem, Etik-Ahlak Felsefesi- (İstanbul: Say Yayınları, 2010), 36. 
mümkün olmadığg dile getirilmektedir. ${ }^{4} \mathrm{Bu}$ yüzden bu çerçevelerin birbirini dışladığı varsayımı evrensellik ve tarihsellik salınımında ahlaki bilincin nereye yerleştirileceğini problematik hale getirmektedir. Ahlaki bilincin çerçevesini belirleyen şey geçmişten devrald1ğımız dini, geleneksel ya da kültürel değerler mi yoksa evrensel insani ortak değerler midir?

$\mathrm{Bu}$ makale ahlaki bilince dair evrensel ve tarihsel perspektifi, kartezyen ve hermenötik gibi zıt bağlamlar içinde analiz edecek, küresel bir dünyada "tarihi" olanın ahlaki bilince dair ortak eleştirel alanın oluşumuna nasıl katkı sunduğunu irdeleyecektir. Başka deyişle pratik tecrübenin "olan" ve "olması gereken" gibi farklı iki boyut arasındaki salınımında tecrübenin "tarihi" niteliğinin evrensel ve tarihsel söylemlerde nasıl tartışıldığı ele alınacaktır. Bu analizin amacı küresel dünyada birbirinden gittikçe soyutlanan fakat birbirine daha sık maruz kalan insani ilişkilere dair eleştirel ve özgür bir alanın nasıl anlamlandırıldığına dikkat çekmektir. Dolayısıyla bu makale ahlaki hakikati anlamlandırmada, tecrübenin geçmiş ve gelecekle ilişkisi bağlamında "tarihi" niteliğinin ahlaki bilince dair evrensel ve tarihsel söylemleri üretmesindeki etkisini irdeleyecektir.

Ahlaki bilincin şekillenmesinde tarihi sürecin nasıl anlamland1rılacağ1 meselesi şimdi-burada tecrübe etmekte olduğumuz dünyanın pratik boyutunun nasıl yorumlandığıyla yakından ilişkilidir. Küresel dünyada kendi mevcut tecrübesinden soyutlanmaya zorlamaksızın, farklılığı anlamlı kılabilecek ve kendi dünyasının sınırlarına dair eleştirel düşünceye açık kalabilecek ahlaki bilincin anlamlandırılmasında pratik tecrübenin "tarihi" vasfı nasıl bir imkân alanı barındırmaktadır? Bu imkân evrensellik ve tarihsellik perspektiflerinde nasıl anlamlandırılmaktadır?

\section{Tarihi “Olan”dan Kopuş Bağlamında Ahlaki Bilincin Evrenselliği}

Evrensellik düşüncesi, tüm insanların halihazırda tecrübe ettiği pratik dünyanın farklılıklarından soyutlanabilen bir bağlam ile ahlaki bilincin teşekkülünü mümkün görmektedir. Mevcut tecrübenin pratik boyutunu tarihi bağlamından soyutlayan bu perspektif, ahlaki

4 Rabiye Çetin, "Metin-Yorum İlişkisi Bağlamında Evrenselcilik-Tarihselcilik Karşılaştırması", İslam ve Yorum Yorumun Tarihsel-Düşünsel Bağlamı ve Güncel Toplumsal Hayata Yansiması, haz.: Fikret Karaman (Malatya: Malatya İlahiyat Vakfı, 2017), 176. 
Tarihle Etkileşimi Bağlamında Ahlaki Bilincin Evrenselliŏgi ve Tarihselliọ̆i Problemi hakikate dair nesnel ve ideal bir zemini mümkün görmektedir. Nitekim bu yoruma göre tarihi olanın pratik boyuta etkisinden bağımsız olarak akıl, soyut rasyonel zeminde ahlaki hakikati nesnel ve ideal düzeyde kavrayıp evrensel bir boyuta erişebilir. Bu nesnel ve ideal zemin, ahlaki bilincin "en iyi" arayışını besleyen eleştirel alanı temin etmektedir. Öyleyse bu perspektife göre bilincin, tarihi vasfından soyutlanıp ahlaki olanı anlamlandırabilmesi için "olması gereken", temel hareket noktasını oluşturmaktadır. Yani evrensellik perspektifine göre ahlaki hakikati ideal ve nesnel kavrayış, "olması gereken"in ufkunda temellendirilmektedir. Bu sebeple "olması gereken" ideal çerçeve, ahlaki bilince dair evrensel bir söylemi dile getirmektedir. Dolayısıyla bu söylem herkes için ideal ve nesnel çerçevede tecrübe edilebilen ortak ahlaki bir alanın varsayımını dile getirmektedir. "Olması gereken" eksenindeki ahlaki hakikatin ideal ve nesnel kavranışı olarak evrensellik düşüncesi kendisini felsefe tarihinde nasıl temellendirmektedir?

Evrensellik düşüncesinin en meşhur biçimi "Ahlak Metafiziğinin Temellendirilmesi" isimli eserde Kant tarafindan dile getirilmektedir. Kant her yerde ortaya fırlayan sevgili Ben'e toslamayı (stö $\beta t)^{5}$ ahlaki bir sorun olarak ortaya koymaktadır. Çünkü bütün insanların sahip olduğu doğal amaç kendi mutlulukları olduğundan pratik ortam içinde Ben insanlıkla negatif bir uyuşma içerisindedir. ${ }^{6} \mathrm{Bu}$ yüzden ahlaklı olmada pratik dünya ile bağı koruyan insanın doğal yapısı, yetkinliği, mutluluğu, duygusu ya da Tanrı korkusu gibi gerekçelerle $^{7}$ ahlaki bilincin teşekkül ettirilmesine şüphe ile yaklaşmaktadır. Çünkü bu boyutlar, tutarlı ve kesin şekilde ahlaki bilince zemin oluşturamazlar. Bu sorunun aşılması ise mevcut pratik dünyanın tüm farklılıklarını ve çeşitliliklerini aşan Ben'in bizzat kendi istemesine dayalı ahlak yasası ile mümkün görünmektedir. Ahlaki bilince dair Kant'ın temel aldığı sorun, öznel olanın nasıl nesnel bir geçerlilik kazanacağına ${ }^{8}$ ilişkindir. Ona göre ahlak yasası, isteme için zorlayıcı olduğu ölçüde nesnel bir ilkeye ${ }^{9}$ dönüşmektedir. Bu zorlayıcılık ancak pratik ortam içinde farklı ahlaki kaygılarla çeşitlenen

5 Kant, Ahlak Metafiziğinin Temellendirilmesi, çev.: İoanna Kuçuradi (Ankara: Türkiye Felsefe Kurumu, 2018), 23.

$6 \quad$ Kant, Ahlak Metafiziğinin Temellendirilmesi, 48.

7 Kant, Ahlak Metafiziğinin Temellendirilmesi, 26.

8 Paul Ricoeur, Yoruma Dair Freud ve Felsefe, çev.: Necmiye Alpay (İstanbul: Metis Yayınları, 2007), 36.

9 Kant, Ahlak Metafiziğinin Temellendirilmesi, 29. 
Ben'den soyutlanabilen zihni alan içerisinde anlamlandırılabilir. Bu sebeple bilincin, ahlaki hakikate nesnel geçerliliğini kazandırabilmesi ancak Ben'in bütün pratik ilgilerinden soyutlanabilen ${ }^{10}$ zaman dışı soyut zihni alanda mümkün görünmektedir.

Buradan anlaşılmaktadır ki, Descartes'la başlayan düşünme biçimiyle zihnin kendi kendisinin farkındalığı ve zihnin kendi gözleriyle kendisine bakmasını sağlayan bir yeti olarak zihinselliğe indirgenmiş bilinç ${ }^{11}$ dahilinde Kant ahlaki hakikati tartışmaktadır. O, ancak ve ancak bu zihni alanda insanın mevcut pratik dünyasının tarihi "olan" 1 etkisinden arınabileceği ve ahlaki hakikate dair evrensel söylem üretebileceğini iddia etmektedir. Yalnızca bu soyut rasyonel aklın yasaları ile ahlaki bilinç, tarihi olandan özgürleşip ahlaki hakikate dair evrensel düzeyde söylem üretebilir. Böylelikle tarih düşüncesini tahrip eden evrensellik düşüncesi harekete geçer. Bu özgürleşme temelinde evrensel ahlaki bilinç oluşturulabilir ve herkes için "en iyi" olana dair ahlaki yaşam teminat altına alınabilir. Zira bu özgür alan, miras olarak devraldığımız tarihi olanın gölgesinden kurtulabileceğimiz ve ahlaki hakikati "en iyi” çerçevesinde tecrübe edebileceğimiz, tüm insanları kuşatan ve bir araya getirebilen nötr noktayı temsil eder. Öyleyse bu perspektife göre ahlaki hakikatin "ne" olduğunun tartışılabileceği böyle bir nötr nokta ancak "olması gereken" bağlamında en geniş söylem çerçevesine erişilebilmektedir. Bu durumda evrensellik düşüncesi, ahlaki bilinç için nesnel ve ideal soyut noktayı "olması gereken" zemininde tasavvur etmektedir. Bu sebeple Batı düşüncesi "finis" ve "telos" olarak bir düzen ve anlam atfettikleri tarihin asıl mihrakını gelecek ${ }^{12}$ boyut içerisinde "ideal" bir tasarım olarak ele almaktadır. Başka bir ifadeyle tarihin "evrensel" hale getirilmesi teleolojik ve eskatolojik tasarımla mümkündür ki bu da insanlık için yalnızca bir fikir ve gelecek ideali ${ }^{13}$ içinde anlamlı kılınabilmektedir. Bu durumda ahlaki bilincin "en iyi" çerçevesindeki arayışında eleştirel ve özgür alan ancak geçmişten tamamen özgürleşen ve geleceği tasarlayan nesnel ve ideal kavrayış zemininde mümkün görünmektedir. Bu sebeple evrenselci felsefe, felsefenin görevini evrenselin bilgisine, Hakikat'e

10 Albert Casullo, "A Priori Knowledge", A Companion to Epistemology, eds.: Jonathan Dancy vd. (West Sussex: Black-Well, 2010), 43.

11 Özlem, “Tarihsellik ve İnsan”. Felsefe Tartışmaları Dergisi, 24 (1999): 18.

12 Karl Löwith, Tarihte Anlam, çev.: Caner Turan (İstanbul: Say Yayınları, 2012), 3637.

13 Löwith, Tarihte Anlam, 36. 
Tarihle Etkileşimi Bağlamında Ahlaki Bilincin Evrenselliŏgi ve Tarihsellioği Problemi rasyonel yoldan ulaşmak olarak koyarak tarihin etkisinden bağımsızlaşma gereği hissetmektedir. ${ }^{14}$ Dolayısıyla geleneksel söylemlerde ${ }^{15}$ ahlaki hakikate dair tarihi "olan"1n pratik tecrübede tekrar ve taklidine dayalı geçmişin idealize edildiği perspektife karşı evrensellik söyleminin alternatif bir yaklaşım arayışında olduğunu iddia edebiliriz. Bu yüzden geleneksel söylemin aksine evrensellik düşüncesi "olan"ın tarihi vasfından bağımsızlaşabildiği ölçüde ahlaki bilinci olanaklı görmektedir. Çünkü tarih alanı, tekilliğin, değişmenin, oluşun, hareketin, düzensizliğin, bir defada olup bitmenin ve gitgide irrasyonelliğin alanı olarak eleştirilmektedir. ${ }^{16} \mathrm{Bu}$ sebeple mantıksal fakat irreel olarak tasvir edilen evrensellik söylemi hep var olan veya ulaşılacak olan bir şey, bir tür erek olma niteliği ile Batı düşüncesine özgü bir mitos olarak ifade edilmektedir. ${ }^{17}$ Bütün insanlar için bağlayıcı olabileceği varsayımıyla ideal ve nesnel bir erek olarak ahlaki bilincin imkanını tartışma ya da ahlaki bilinci buradan hareketle yorumlama, Kant'ın dile getirdiği şekilde ahlakın yasa olarak tasarlanmasına denk düşmektedir. Yasa bağlamında "en iyi" yi soruşturan ahlaki bilinç ise tarihin etkisindeki tekil olanın biricikliğini "ideal" uğruna göz ardı etmektedir. Tekilin biricikliğini göz ardı eden ve tarihi olandan bağımsızlaşmayı mümkün kıldığ1 varsayılan bu "ideal" çerçeveyi eleştiren hermenötik düşünce, geçmişin pratik tecrübe üzerindeki belirleyiciliği ve tamamen ortadan kaldırılamaz etkisi bağlamında ahlaki bilince dair söylem geliştirmektedir.

\section{Tarihi "Olan"ın Kuşatıcılığı Bağlamında Ahlaki Bilincin Tarih- selliği}

Günümüzde hermenötik düşünce, ahlaki hakikati kavrarken bilincin "tarihi" olanın etkisinden tamamen bağımsızlaşabilmesini

14 Doğan Özlem, "Felsefi Hermenötiğe Geçiş Yolu Olarak Tarihselcilik", Ankara Üniversitesi Illahiyat Fakültesi Dergisi, 40/1 (1999): 130.

15 Makalede kullandığımız "geleneksel söylem" ifadesi tarihte belirlenmiş herhangi bir özel zaman dilimine işaret etmemektedir. Antik Çă̆, Orta Çă̆, Aydınlanma Çağı veya Küresel Çağ olarak addedilen herhangi bir zaman dilimindeki bilincin, devraldığı kültürel, dini, felsefi vs. geleneğine karşı eleştirel ve sorgulayıcı tutumdan yoksun yüzleştiği yeni ve farklı sorunları geleneğini taklit ve tekerrür ederek aşabileceği varsayımını ifade etmektedir.

16 Özlem, "Felsefi Hermenötiğe Geçiş Yolu Olarak Tarihselcilik", 130.

17 Doğan Özlem, "Evrenselcilik Mitosu ve Sosyal Bilimler", Sosyal Bilimleri Yeniden Düşünmek Yeni Bir Kavrayışa Doğru (İstanbul: Metis Yayınları, 2001), 54. 
mümkün kılan soyut "ideal" çerçevenin varlığını, geçmiş olanın etkisini ve belirleyiciliğini ön plana çıkararak eleştirmektedir. $\mathrm{Bu}$ perspektifte dil ve tarih, anlama olayını kuşatan ve daha ötesine gidilemeyen temel bir zemin olarak varsayılmaktadır. Bu temel zeminden hareket eden ahlaki bilinç, geçmişin yok edilemez etkisi nedeniyle tarihsel niteliği haiz olmaktadır. Dolayısıyla tarih ve dil, bilincin "değişen a priorileri" olarak kabul edilmektedir. ${ }^{18}$ Fakat bu a prioriler doğaları itibariyle değişmeye açık olduklarından yani daima farklı bağlamlarda farklı olduklarından nihai teorik bir çerçeve içerisinde ifade edilmeye çalışılmaz. ${ }^{19} \mathrm{Bu}$ perspektif, bilincin tarihi süreçle temel bir ilişkiye sahip olduğunu ve anlamanın tarihsel durumla koparılamaz bir bağı olduğunu iddia etmektedir. ${ }^{20} \mathrm{Bu}$ bağlamda tarihsellik/tarihsel oluş (Geschichtlichkeit), insanın tarihe ait olana katılımını ve tarihe ait olanla etkileşimini göstermek amacıyla kullanılmaktadır. ${ }^{21}$ Heidegger'e göre,

... tarihten kurtulmak mümkün değildir. Burada tarih, mazide olup da etkisi hala devam eden, demektir. .... Mazi anlamindaki tarihsel olan, "şimdiyi" müspet veya olumsuzlayan etkileri bakımından "şu anda" ve "bugün" gerçek olan olarak anlaşılmaktadır. ... tarih mazide kalanlar anlamındaki "geçmişi" değil, geçmişteki menşei de ifade edebilmektedir. "Tarihi olan" bir şey, belirli bir oluşla irtibatlıdır. ... Burada tarih, "geçmiş", "bugün" ve "geleceğe" uzanan bir hadise ve "tesir rabitasını" imlemektedir. ... Tarih var olmakta olan Dasein' in zaman içinde cereyan eden ve ona has olan yaşanmışlıklarıdır, öyle ki, hep-beraber-olmaklık dahilinde "mazide kalan" ve fakat aynı zamanda "nakledilmiş olan" ve etkisini devam ettiren yaşanmışlıklar ve özellikle ve vurgulu anlamda tarih olarak kabul edilmektedir. ${ }^{22}$

Heidegger, "tarih" kavramı içinde "geçmişin" tuhaf önceliği ve kurucu rolüne bu şekilde dikkat çekmektir. ${ }^{23} \mathrm{Bu}$ öncelik ile geçmişin mevcut tecrübeyi kuşatan boyutu dile getirilmektedir. Kısacası

18 Wachterhauser dil ve tarih ile ilgili bu yorumu yaparken Habermas'ın “değişen a priori (transitory a piriori)" kavramını borç aldığını belirtmektedir. R. Wachterhauser, "Anlamada Tarih ve Dil", Insan Bilimlerine Prolegomena, der.: \& haz.: Hüsamettin Arslan (İstanbul: Paradigma Yayınları, 2002), 210.

19 Wachterhauser, "Anlamada Tarih ve Dil", 210.

20 Wachterhauser, "Anlamada Tarih ve Dil", 212.

21 Wachterhauser, "Anlamada Tarih ve Dil", 211.

22 Martin Heidegger, Varlık ve Zaman, çev.: Kaan H. Ökten (İstanbul: Agora Kitaplığ, 2008), 402.

23 Heidegger, Varlık ve Zaman, 403. 
Tarihle Etkileşimi Bağlamında Ahlaki Bilincin Evrenselliŏgi ve Tarihselliọ̆i Problemi bu perspektifte insanın kendisini ve dünyayı anlama imkanını belirleyen şey tarihtir. ${ }^{24} \mathrm{Bu}$ yorum, tarihte tecrübe edilen olayın etkisini sürdürmesiyle kazandığı "tarihi" sıfatı çerçevesinde, geçmişte vuku bulmuş herhangi bir olayın mevcut tecrübeye etkisini ön plana çıkarmaktadır. Hermenötik bu durumu tasvir eden bir söylem geliştirmektedir. Dilthey'a göre hermenötik söylem, romantik keyfilik ve septik öznelliğin sürekli müdahalelerine karşı, kuramsal temellendirmeyi tarih alanında gerçekleştirmektedir. ${ }^{25}$ Tarih bağlamindaki bu kuramsal temel, Kant'ın öznel olanın nasıl nesnel olacağına dair uğraştı̆̆ı problemde "isteme için bağlayıcı ya da zorlayıcı" etkisini ön plana çıkardığı ahlak yasasına alternatif bir zemin teşkil etmektedir. Gadamer ise tarihi olanın pratik tecrübe üzerindeki bu zorlayıcı etkisini buyurucu ve sınırlayıcı olarak tasvir etmektedir. ${ }^{26}$ Adeta pratik tecrübenin prangasıymış gibi "geçmiş", pratik tecrübe üzerinde anlamlı konuşmayı ve onun eleştirisini yapmayı mümkün kılan bağlayıcı mutabık bir alanı teşkil etmektedir. Bu bağlamda tarihsellik, herhangi bir bilgi iddiasının bizatihi anlamının ve geçerliliğinin hem onu formüle edenlerin hem de geliştirenlerin tarihsel durumuyla koparılamaz bir biçimde içi içe olduğu yolundaki çok radikal bir iddiayı içermektedir. ${ }^{27} \mathrm{Bu}$ radikal iddia, evrenselliğin ahlaki bilinç için varsaydığı ideal ve nesnel eleştirel alanın imkanına şüphe ile yaklaşmakta; geçmişin sürekliliği ve bağlayıcılığı ekseninde ahlaki bilincin eleştiri alanını anlamlı kılmaktadır. Fakat bu tarihsel perspektifte ahlaki bilinç, özgürlüğünü nasıl anlamlandırmaktadır? Başka bir deyişle kendisini tarihi “olan”ın etkisi bağlaminda idealize eden geleneksel söylemlerden nasıl ayrılmaktadır?

Hermenötik düşünce, bilincin tarihselliği ile mevcut tecrübe tarzımızın, daha önceki bir ufuk tarafından belirlenmiş ve zamana ait kılınmış yönüne işaret etmektedir. Hermenötik düşüncenin böyle bir kuramsal çerçeveden hareket etmesi "olması gereken"in, “olan”ın etkisi ile şekillenmekte olduğunu göstermektedir. Habermas'ın ifadesiyle geçmiş ile geleceğin, aynı anda birbirine geçen

\footnotetext{
24 Wachterhauser, "Anlamada Tarih ve Dil", 213.

25 Wilhelm Dilthey, "Hermeneutiğin Doğuşu”, çev.: Doğan Özlem, Felsefe Tartışmaları, 22 (1997): 103.

26 Hans George Gadamer, Hakikat ve Yöntem, II, çev.: Hüsamettin Arslan \& İsmail Yavuzcan (İstanbul: Paradigma Yayıncılık, 2009), 56.

27 Wachterhauser, "Anlamada Tarih ve Dil”, 212.
} 
ufukları içinde cereyan eden bu durum, tarihsellik bilincini meydana çıkarmaktadır. ${ }^{28}$ Zira birbirleriyle iç içe geçen bu ufuklar bir şeyi nasıl anlamakta olduğumuza dair sınırları teşkil etmektedir. Bu sınırlar da bir nevi hangi eşikte durduğumuza ve hangi sınırlar dahilinde hakikatle ilişki kurduğumuza işaret etmektedirler. Bu durum hem tarih tarafından belirlenmiş bilinci, hem de bu belirlenmişliğin bilincinde olmayı ifade eder. ${ }^{29} \mathrm{Bu}$ yorum bağlamında hermenötik düşünce ahlaki bilinci, mevcut tecrübenin "tarihi" vasfının etkisi ve belirleyiciliğinden bağı koparmayarak "olması gereken"e dair tartışmayı köklere ve zemine doğru bir hareket ile anlamlandırmaktadır. Zira evrensellik düşüncesinde olduğu üzere ahlaki bilinç için ideal ve nesnel bir tasarım sunmak yerine mevcut geleneksel "olan" zemini hareket noktası varsaymaktadır. Bu zeminde ahlaki bilinç, gizli kalan bu kökün -"olan"ın-, "olması gereken"in anlamı üzerindeki belirleyiciliği ve zorlayıcılığını deşifre edebilmektedir. Fakat bu perspektifte pratik tecrübe "tarihi" olandan soyutlanamayacağına göre ahlaki hakikate dair "en iyi" eksenindeki soruşturma, ancak mevcut olan sınırların fark edilmesiyle yürütülebilir. Bir bakıma hermenötik düşünce, tarihin gizli kalan baskı ve kuşatıcılığındaki sis perdesini aralayarak ahlaki hakikatin tecrübesindeki biricik boyutu ön plana çıkarmak istemektedir. Her ne kadar değişimin ve farklılığın odağa yerleştirildiği küresel dünyada ahlaki hakikati tecrübe etmenin biricikliği vurgusu göze çarpsa da bu tecrübenin "en iyi" ekseninde sürekli sorgulanması ve zenginleştirilmesi için bağlayıcı eleştirel alanın nasıl anlamlandırılacağı hala bir problem arz etmektedir. Hermenötik düşünce pratik tecrübenin tarihsel vasfından hareketle bu problemi yeniden anlamlandırmaktadır. Böyle bir perspektiften hareket ettiğimizde ahlaki hakikat, zamansal ve tarihsel bir olaydır ve ahlaki ifadeler aracılığıyla tecrübe edilebildiği halde bu ifadeler evrenselleştirilemez. ${ }^{30}$ Tarihsel olarak belirlenmiş bu sınırlar dahilinde ahlaki hakikate dair "en iyi" olanın soruşturulmasında bilincin tarihsel dolayımının eleştirisini yapmanın önemi ve gerekliliği Nietzsche'nin şu satırlarından da okunabilir:

28 Jürgen Habermas, İnsan Doğasının Geleceği, çev.: Kaan H. Ökten (İstanbul: Everest Yayınlar1, 2003), 10.

29 Burhanettin Tatar, Felsefi Hermenötik ve Yazarn Niyeti (Ankara: Vadi Yayınları, 1999), 120.

30 Burhanettin Tatar, "Ahlaki Hakikatin Zamansallı̆̆ı", Çağdaş Sorunlar Spekülatif Düşünceler (Samsun: Etüt Yayınları, 2008), 43. 
Tarihle Etkileşimi Bağlamında Ahlaki Bilincin Evrenselliŏgi ve Tarihselliọ̆i Problemi İster bir insanda ya da toplumda, ister bir kültürde olsun, uykusuzluğun, geviş getirmenin, tarih duygusunun bir sınırı vardır, bu sınıra gelip dayandı mı, yaşayan bundan zarar görür ve sonunda yok olup gider. Ĕ̆er geçmişin bu sınırı (ölçü) ile bugünün mezar kazıcısı olması istenmiyorsa, onun unutulması gereken sınırını belirlemek için, bir insanın, bir ulusun, bir kültürün plastik gücünün ne denli büyük olduğunun iyice bilinmesi gerekir; plastik güçle demek istediğim, kendi içinde kendine özgü bir biçimde gelişen güç, geçmiş ve yabancı olanın biçimini değiştiren, yaraları iyileştiren, yitirileni yerine koyan, kırılan biçimlere kendi içinden yeniden bir biçim veren güç." 31 ... “Öyleyse tarih-dışı olanı duyabilme, sezebilme yetisini daha önemli ve daha öncelikli yeti olarak göz önüne almamız gerekecek" 32 ... "insanın düşünerek, düşünüp taşınarak, karşılaştırarak, ayırıp birleştirerek o tarih-dışı öğeyi sınırlamasıyla, o ortalığı kuşatan sis bulutlarının içinde aydınlık, parlak bir ışığın doğmasıyla, şimdi, ancak geçmişi yaşam için kullanmak ve olup bitenlerden yeniden tarih yapmak, yaratmak gücüyle, insan insan olabilir: ama tarihi aşırı derecede kullanınca da insan yeniden tükenir; tarih-dışı olanın o örtüsü olmadan da insan hiçbir zaman için bir şeye başlayamayacaktı ve başlamaya da cesaret edemeyecekti. ${ }^{33}$...tarih aşırı güç kazanırsa yaşam parçalanır ve soysuzlaşır.. ${ }^{34}$

Bu metin, ahlaki hakikatin tarihsel ve sınırlı "olan" bağlamının "en iyi" ekseninde zenginleştirilebilmesi için eleştirel alanın canlılığını sürdürmenin önemini bize hatırlatmaktadır. Bu hatırlatmada tarih, insanın varoluşuna dair bir hafızada neşvünema bulmaktadır. Ricoeur'ün ifadesiyle hafıza tarihin ana rahmidir. ${ }^{35} \mathrm{Bu}$ sebeple hafıza/hatırlama, bilincin geçmiş ile kökensel bağının kurulduğu yerdir ve insan bir şeyi hatırladığında kendisini hatırlamaktadır. ${ }^{36} \mathrm{Ni}$ etzsche'ye göre ise insanın "anımsıyorum..." demesi onu hayvandan ayırt eder ${ }^{37}$ ve insanı diğer varlıklardan ayıran en köklü varoluş biçimini dile getirir. Nietzsche için "bir zamanlar" sözcüğü, her şeyi

31 Nietzsche, Tarih Üzerine, çev.: Nejat Bozkurt (İstanbul: Say Yayınları, 2000), 6465.

32 Nietzsche, Tarih Üzerine, 67.

33 Nietzsche, Tarih Üzerine, 67.

34 Nietzsche, Tarih Üzerine, 74.

35 Ricoeur, Hafiza, Unutuş, Tarih, çev.: M. Emin Özcan (İstanbul: Metis Yayınları, 2010), 106.

36 Ricoeur, Hafiza, Unutuş, Tarih, 115.

37 Nietzsche, Tarih Üzerine, 62. 
çözümleyen o anahtar sözcük (parola), varoluşun aslında ne olduğunu insana anımsatır ki bu yüzden yaşam sadece kesintisiz "bir zamanlar-varolma" dır. ${ }^{38}$ Tarihi "olan"la bu sürekliliği sağlayan hafıza, bilincin esası olarak dile getirilmektedir. ${ }^{39}$ Zira hafızasını kaybeden kişi herhangi bir anlamlandırmada bulunamaz. Bu nedenle geçmişini unutup hafızayı kaybetme "bitkisel yaşam" ile tasvir edilmektedir. ${ }^{40} \mathrm{Bu}$ durum, hafızanın mevcut an ile geçmiş ve gelecek arasında bağ kurucu hayati işlevini dile getirmektedir. Dolayısıyla evrensellik düşüncesinin aksine hermenötik düşüncenin, bilincin mantıksal yapısından ziyade hafıza bağlamındaki niteliğine atıfla bir yorum geliştirmekte olduğunu iddia edilebiliriz. Bilincin hafıza bağlamındaki niteliği vasıtasıyla geçmişin izleri aydınlatılır ve pratik tecrübenin mevcut sınırlarının ötesine dair konuşma anlamlı kılinabilir.

Bu nokta, hermenötik düşüncenin, "olan"1 idealize eden geleneksel söylemden farkına da işaret etmektedir. Öyleyse hafıza olarak bilinç, "olması gereken"e dair geçmişin taklit ve tekerrürü d1şında özgür ve eleştirel yeni bir alanı ancak mevcut bağlayıcı sınırları göz önünde bulundurduğumuzda mümkün görmektedir. Ancak bu imkân dahilinde insan zihni, tarih gerçekliği ve dil gelenekleri karşısında kendine özgü (mesafeli) bir konuma sahip olarak gelenek (sosyal bilinç) tarafından belirlenen sınırı aşar. ${ }^{41} \mathrm{Bu}$ perspektifte tarih sahnesi, "olan"1n tekerrürü çerçevesinde pratik tecrübeyi belli kalıplar içinde sıkıştıran ve katılaştıran ya da onu idealize eden bir yer değil; bilakis mevcut ufkun deşifre edilerek "olması gereken"e dair eleştirel bilinci diri tutan zorlayıcı bir zemini teşkil etmektedir. Buradan mülhem tarihsellik, varllğımızın nasıl şekillendiğine ve belirlendiğine dair bize bir şeyler söyleyerek ${ }^{42}$ mevcut ufkun sınırlarına dair eleştirel bir söyleminin gerekliliğine dikkat çekmektedir. Bu söylemde eleştirel fonksiyonu bakımından "ufuk" kavramı hermenötik düşüncenin merkezi kavramlarından birini teşkil etmektedir. Zira "ufuk" kavramı, kendisini anlamaya çalışan kişinin sahip olması gereken daha üstün bir vizyon genişliği olarak

\footnotetext{
38 Nietzsche, Tarih Üzerine, 62-63.

39 Teoman Duralı, "Tarihin Dayanılmaz Ağırlığı”, Ankara Üniversitesi İlahiyat Fakültesi Dergisi 40/1 (1999): 121.

40 Duralı, “Tarihin Dayanılmaz Ağırlı̆̆ı”, 121.

41 Tatar, Felsefi Hermenötik ve Yazarm Niyeti, 11.

42 Tatar, "Ahlaki Hakikatin Zamansallığı”, 49.
} 
Tarihle Etkileşimi Bağlamında Ahlaki Bilincin Evrenselliŏgi ve Tarihselliọ̆i Problemi tanımlamaktadır. Dahası ufuk kazanmak insanın menzili içinde kalan şeyin ötesine bakmayı öğrenmesi anlamına gelir. ${ }^{43}$

Bu bağlamda hermenötik düşüncede ahlaki bilinç, mevcut tecrübeyi, şimdi burada vuku bulanı, sınırsız bir ufuk bağlamında anlamlandırma çabasıdır. Dolayısıyla miras aldığımız tecrübeye eleştiriden uzak hazır bir anlam yüklenmesine dair bilince, eleştirel ve özgür bir alan açar. Çünkü Gadamer'e göre tarihsel olmak, kişinin kendisi hakkındaki bilgisinin asla tam olamaması demektir. ${ }^{44}$ Böylece mantık değil hafıza bağlamında ahlaki bilinç, kanaatimizce dünyanın pratik boyutunun tarihi olanla ilişkisini koparmadan "olan" ile "olması gereken" arasındaki mesafede konumlanmaktadır. Tatar'a göre "olmalı/olan" (ought/is) diye adlandırılan sorun ahlaki ilkelerin evrenselliği ile ahlaki tecrübelerin zamansallığı arasındaki aşılamaz boşluğu yansıtır. Bununla birlikte ahlaki hakikat ne "olmalı" ne de "olan" alanına hapsedilebilir. ${ }^{45} \mathrm{Bu}$ iddia bağlaminda ahlaki hakikati anlamlandırmada "olan" ile "olmalı" arasındaki mesafenin korunması, bu bağlayıcı sınırlar hakkında eleştirel ve özgür alanın anlamlandırılabilmesi için öncelikli meseledir. Böylece hafıza bağlamında izini sürdügüumüz tarih, bu mesafenin üretilebilmesi için bilince, hem zamanda geriye gitme hem de zamanı kat etme yeteneğini ${ }^{46}$ bahşeder.

Bu mesafenin tecrübesinde ahlaki bilinç, ne geleneksel söylemdeki "olan"1 ne de evrensellik düşüncesindeki "olması gereken"i idealize etmektedir. Zira hangi perspektiften hareket ederse etsin ahlaki bilinci herhangi önceden belirlenmiş, sabit noktaya göre idealize etmek, ahlaki hakikatin tecrübesindeki biricik boyutu göz ardı etmekte ve onu yasa çerçevesine indirgemektedir. Bu indirgeme bir bakıma "olan" ve "olması" gereken arasındaki mesafeyi ortadan kaldırmaktır. Öyleyse ancak "olan" ve "olması gereken" in arasındaki mesafenin bitimsiz olduğunu tasvir ettiğimizde ahlaki bilinç için özgür ve eleştirel bir alanı anlamlandırmak mümkün görünmektedir. Hermenötik düşünce, bilincin geçmişin etkisinden tamamen bağımsızlaşamayacağını ön plana çıkararak ahlakın bu iki boyutu -"olan" ve "olması gereken"- arasındaki mesafenin aşılamaz olduğunu vurgulamaktadır. Böylece kartezyen düşüncede zihni

\footnotetext{
Gadamer, Hakikat ve Yöntem, II, 60.

Gadamer, Hakikat ve Yöntem, II, 56.

Tatar, "Ahlaki Hakikatin Zamansallığı", 50.

Ricoeur, Hafiza, Unutuş, Tarih, 115.
} 
alanda belli ilkeler çerçevesinde ölçülüp "ideal" ve "nesnel" olarak kat edilebilir varsayılan bu mesafe, hermenötik perspektif bağlamında bitimsiz bir sürece işaret etmektedir. Kanaatimizce bu tasvir bağlamında ahlaki bilinç, hem ahlaki hakikatin yasayı aşan biricikliğini dikkate alabilir hem de özgür-eleştirel alanı canlı tutarak "en iyi"ye dair arayışı anlamlı kılabilir.

Bu bağlamda Hermenötik düşünce, bilincin odağına "tarihi" olanı yerleştirerek "olmalı/olan" (ought/is) arasındaki boşluğa insanı yerleştirerek ahlaki hakikatin "ne"liği konusunda determinize olmuş ahlaki bilince kapılarını kapatmaktadır. Zira Gadamer'e göre tarih her türlü rasyonel düzene karşı direnç göstermektedir. ${ }^{47}$ Pratik tecrübenin geçmişe bağlı "olan" boyutu bilincin mevcut sınırlarına işaret ederek "olması gereken" $i$ anlamlandırmada ahlaki bilinç için belli bir direnç ya da test mekanizması olarak işlemektedir. Gadamer bilimdeki ilerleme ve teknolojik mükemmellik idealinin yayginlaştı̆̆ı uygarlıklarda geçmiş direncini kaybettiği için yenilik ve değişikliğin zora gireceğini iddia etmektedir. ${ }^{48} \mathrm{Bu}$ iddianın ahlaki ilişkilerde yarattığı sorun pratik tecrübede "tarihi" olan direncini yitirdiği ölçüde ahlaki bilince dair eleştirel alanın zayıflamakta olduğudur. Zira hermenötik düşüncede tarihi anlamak, "bizi tarih içinde konuşan ve ona ait bir şey kılan şey"i anlamaktır ki bu bir ufuk ya da sınır durumu olarak "geleceğimizin olanakları"nı yönlendirmektedir. ${ }^{49}$

Kanaatimizce bu durumun göz ardı edilmesiyle "en iyi"ye dair ahlaki bilinç, anlam kaybına uğramaktadır. Zira tarihi olan direncini kaybettiği oranda "olan" ve "olması gereken" arasında mesafe aşınmakta bu durum ise "en iyi" olanı arayıştaki eleştirel bilinci zayıflatmaktadır. Örneğin modernizmin güçleri sayesinde, sınırsız bir kendini ortaya koyma (self-realization), otantik şekilde kendini duyumlama deneyimi (self-experience) isteğinin, aşırı uyarılmış bir

47 Gerald L. Bruns, “On The Coherence Of Hermeneutics and Ethics An Essay On Gadamer and Levinas", Gadamer's Repercussions Reconsidering Philosophical Hermeneutics, ed. Bruce Krajewski (California: University of California Press, 2004), 46.

48 Gadamer, "Tarih Bilinci Sorunu”, Toplum Bilimlerine Yorumcu Yaklaşım. çev.: Taha Parla (İstanbul: Hürriyet Vakfı Yayınları, 1990), 83.

49 Özlem, Tarih Felsefesi, 259. 
Tarihle Etkileşimi Bağlamında Ahlaki Bilincin Evrenselliŏgi ve Tarihselliọ̆i Problemi duygusal öznelciliği hâkim kılarak hedonistik motifleri serbest kıldığına dair eleştirijo günümüzde bu mesafenin aşındığına işaret etmektedir. Çünkü evrenselciliğin varsaydığı üzere ideal ve nesnel bir ahlaki yasa tasarımının, küresel dünyada, bilinç için ortak eleştirel bir zemini tesis etmedeki etkisiz işlevi, Ben merkezinde hedonistik tutumlara karşı eleştirel bir işlev ortaya koyamamaktadır. Bu durum ahlaki bilincin, tarihsel dolayımın fark etmesi ve sorgulayabilmesini mümkün kılan alternatif yorum ve tartışmaların önemini ortaya çıkarmaktadır. Gadamer'in ön anlama kavramı ekseninde yorumladığı gelenek düşüncesi mevcut tecrübenin "daha iyi" olanı arayışta ahlaki bilince alternatif bir tartışma sunmaktadır. Ön anlama kavramı bir sınırın eşiğinde durduğumuzun kabul edilmesidir ${ }^{51}$ ve ancak bu kabul ile bu sinırın ötesi hakkında sorgulama mümkün görülmektedir. Bu sorgulama, geleneksel söylemi belirlenmiş bir "en iyi" formuna sıkıştırmadan eleştirel bir boyut açma imkânı sunabilir. Fakat hermenötik düşünce bağlamında bu eleştirel boyut, bu "öteye geçiş", tecrübe edilen dünyada tarihi olanın etkisinden soyutlanamadığı için "evrensel bir hakikat"i değil, farklı sınır tecrübelerine dair bir anlama ve yorumu ifade etmektedir. Özlem, bu durumu şu şekilde dile getirmektedir:

Hermeneutik, insanın tasarlayıp gerçekleştirdiği her şeyin tarihsel olduğu ve kaldığına ilişkin temel tarihselci teze dayanacaktır. $\mathrm{Bu}$ tez ayn zamanda insanın kendisini tanıma/bilme imkanının tarihte bulunduğu tezini de zaten içerir. Bu tanıma/bilme, tek bir edimmiş gibi görünen bir edimler birlikteliği olarak, "anlama" adını alır. Yaşamın ve tarihin herhangi bir dönemi, birçok yönden bir sanat eseri gibi, kurulan, inşa edilen, yaratılan bir şeydir. Bir sanat eseri karşısında nasıl ki tüm benliğimizle, sahip olduğumuz tüm yetilerin birlikte harekete geçmesiyle bir tavır alıyor ve o sanat eserini anlama şansımızı ancak böyle bulabiliyorsak; bir tarihsel dönem de

50 Habermas, İnsan Doğasının Geleceği, 34.

51 Gadamer'e göre “Tarihsel bilinç kendi ötekiliğinin farkındadır ve bu yüzden geçmişin ufkunu kendi ufkundan hareketle ön plana çıkarır/kendi ufkunda temellendirir. Kaldı ki göstermeye çalıştı̆̆ımız gibi, tarihsel bilincin kendisi yalnızca süregiden geleneğe empoze edilmiş bir şeydir; dolayısıyla bu yolla kendisini kendisinden hareketle ön plana çıkardığ $1 /$ kendisinde temellendiği şeyle yeniden birleştirir; kendisini tekrar bu yolla kazandığı tarihsel ufkun birliğinde ifade etmek için yapar. Demek oluyor ki bir tarihsel ufku geleceğe yansıtmak anlama sürecinin fazlarından biridir sadece; bu, tarihsel ufku geçmişi bilincin kendisineyabancılaşmasında dondurmak değil, bizim şimdiki anlama ufkumuzla buluşturmaktır." Bk. Gadamer, Hakikat ve Yöntem, II, 62-63. 
ancak bir edimler birlikteliği olarak "anlama" yoluyla kavranabilir. Ve anlama, bir edim ve yöntem olarak, tarihte tekil halde gerçekleşenleri, yine kendi tekillikleri ile tanıma/bilme edimi ve yöntemidir ve bu edim ve yöntemle elde edilen ilgi de ancak "yorum" adını alabilir. ${ }^{52}$

Dolayısıyla böyle bir yorum perspektifinden hareket eden ahlaki bilinç için "en iyi", ideal ve nesnel olarak kavranan soyut bilişsel, epistemolojik ${ }^{53}$ sürece değil, daha çok farklı perspektifler ekseninde sürekli genişleyen ve sorgulanabilen somut varoluşsal bir ufka işaret etmektedir. Bu sebeple 19. yüzyıl boyunca kendini bütün belirli tarihsel bağlardan kurtaran radikal bir modernlik bilincinin doğmasıyla tarihsel referans noktasını tamamen yitiren ${ }^{54}$ bir bilincin eleştirisi olarak hermenötik düşünce, sonsuz bir şimdinin ufkunda, kendi kendimizin-bilincinin tarihsel derinliklerine uzanan ${ }^{55}$ alternatif bir eleştirel yorum geliştirmiştir. Bu yorumda ahlaki bilinç, tarihi "olan"ın kuşatıcılığı bağlamında "en iyi" olanı "bitip tükenmeyen arayış sürecinde" anlamlı kılmaktadır.

\section{Sonuç}

Bu makale ahlaki bilince dair evrensellik ve tarihsellik denkleminde pratik tecrübenin "tarihi" vasfının nasıl yorumlandığına dikkat çekmektedir. Bu yorumda evrensellik düşüncesinin aksine hermenötik düşüncenin mevcut pratik dünyanın "tarihi" vasfını dikkate alarak ahlaki bilince dair eleştirel ve özgür alanı mümkün gördügüüne dikkat çekilmektedir. Dolayısıyla ideal-soyut evrensel ahlak yasalarından hareketle "en iyi" ye dair anlam arayışını yorumlayan kartezyen düşüncenin aksine hermenötik düşünce bilinci kuşatan somut ve zorlayıcı "tarihi" bağlamdan hareket etmektedir. Başka bir deyişle hermenötik düşünce, ahlaki hakikatin tecrübesini ideal ve nesnel

's 'in ahlak öğretisi mutlulukçu, eudaimonist bir öğretidir. mutluluk, insan eylemlerinin en son hedefi, "en yüksek iyi" dir. ... Sokrates, daha önce relativizm-mutlakçıllk/evrensellik tartışması üzerinde dururken de belirttiğimiz gibi bilgisel "doğruluk" $u$ ahlaksal "iyi"ye önceleyen, onu temellendiren bir şey sayar." bk. Özlem, Etik-Ahlak Felsefesi-, 49-50; Ayrıca etikte, erdem (virtue) teorisine benzeyen bir yaklaşımın benimsenmesiyle epistemolojinin faydalı olabileceğini tartışan "virtue epistemology" kavramı ve onlara yöneltilen eleştirel çağdaş tartışmalar için bkz. John Greco, "Virtue Epistemoloji", A Companion to Epistemology, ed. Jonathan Dancy vd. (UK: Black-Well, 2010), 75.

54

Zekâ, çev.: Gülengül Naliş vd. (İstanbul: Kıyı Yayınları, 1994), 32.

346

Gadamer, Hakikat ve Yöntem, 2/59. 
Tarihle Etkileşimi Bağlamında Ahlaki Bilincin Evrenselliŏgi ve Tarihselliọ̆i Problemi zihni alanın aksine pratik tecrübenin tarihi vasfından hareketle yorumlamaktadır. Bu perspektifte ahlaki hakikat, pratik tecrübenin ahlaki boyutunu zihni olarak belirlenmiş ideal bir noktaya göre ölçülmesi değil, ideal olanı arayış süreci olarak anlamlandırmaktadır. Bu bağlamda tarihsellik insanın tarihe ait olana katılımını ve tarihe ait olanla etkileşimini aktivite ederek "en iyi"ye dair arayışı daimî bir süreç olarak olanaklı görmektedir. Bu zemin, ahlaki bilinci "olan" ve "olması gereken" arasındaki mesafeye yerleştirerek ahlaki hakikatin anlamını/neliğini bitimsiz bir süreç olarak tasvir eder.

Böylece ahlaki bilince özgür ve eleştirel ortam sağlayarak daha zengin bir ahlaki tecrübenin arayışını anlamlı kılar. Mevcut pratik dünyanın tarihi vasfını dikkate alan tarihsel ahlaki bilinç, "en iyi" olanın tecrübesinin her daim daha zengin bir tecrübeye gebe olduğunu kavrayan bilinçtir. Dahası o, kendi dünyasının tarihsel sınırlarına dair eleştirel düşünceye açık olduğundan şimdinin sınırlarının ötesine, insanın kendi kendisinin-bilincinin tarihsel derinliklerine uzanır. Bu yorum ahlaki tecrübenin anlamının ahlaka dair bilincimizden her daim daha fazla anlam ihtiva ettiğine işaret etmektedir. $\mathrm{Bu}$ artı anlam hem geçmiş hem geleceğe dair bir ufku barındırır. Bu ufuk, hiç kimseyi kendi dini, geleneksel ve kültürel tecrübesinden soyutlamaya zorlamaz, aksine ahlaki hakikat tecrübesinde onunla sıkı bir ilişki içinde bulunduğuna vurgu yapar. Dolayısıyla bu perspektif farklılıkların çok daha hızlı ve sık şekilde yüzleştiği küresel dünyada tecrübe edilen sınırların tarihsel vasfını ön plana çıkardığı için ahlaki bilincin "en iyi"ye dair arayışını hem anlamlı kılmakta hem de bu arayış için belli mesafede eleştirel ve özgür alana imkan tanımaktadır. Bu süreç içinde hareket ettiğini idrak eden tarihsel hermenötik bilinç, "en iyi"ye dair anlam arayışında nihilist ya da belli çerçeveler içinde sabitlenmiş katı hegemonyacı bir tavra karşıt bir yorum geliştirir. Bu yorum, insanların mevcut tecrübelerini ve bu tecrübeye şekil veren dini, geleneksel, kültürel söylemlerini "en iyi" ekseninde sürekli şekilde sorgulayıp dönüştürebilen eleştirel ve özgür ahlaki bir bilincin geliştirilmesine katkı sunacaktır.

\section{Kaynakça}

Bruns, Gerald L. “On The Coherence Of Hermeneutics and Ethics An Essay On Gadamer and Levinas". Gadamer's Repercussions Reconsidering Philosophical Hermeneutics. Ed. Bruce Krajewskii. California: University of California Press, 2004. 
Casullo, Albert. "A Priori Knowledge". A Companion to Epistemology. Ed. Jonathan Dancy vd. 43-53. UK: Black-Well, 2010.

Çetin, Rabiye. "Metin-Yorum İlişkisi Bağlamında Evrenselcilik-Tarihselcilik Karşılaştırması". İslam ve Yorum Yorumun Tarihsel-Düşünsel Bă̆lamı ve Güncel Toplumsal Hayata Yansıması. Hazırlayan Fikret Karaman, 175-197. Malatya: Malatya İlahiyat Vakfı, 2017.

Dilthey, Wilhelm. "Hermeneutiğin Doğuşu”. Çev. Doğan Özlem. Felsefe Tartışmaları 22 (1997): 92-115.

Duralı, Teoman. “Tarihin Dayanılmaz Ağırlığı”. Ankara Üniversitesi İlahiyat Fakültesi Dergisi 40/1 (1999): 1117- 126.

Gadamer, Hans George. Hakikat ve Yöntem. çev. Hüsamettin Arslan \& İsmail Yavuzcan. İstanbul: Paradigma Yayıncllık, 2009. "Tarih Bilinci Sorunu". Toplum Bilimlerine Yorumcu Yaklaşım. Çev. Taha Parla, 79-106. İstanbul: Hürriyet Vakfı Yayınları, 1990.

Greco, John. "Virtue Epistemoloji”. A Companion to Epistemology. Ed. Jonathan Dancy vd. 75-82. UK: Black-Well, 2010.

Habermas, Jürgen. İnsan Doğasının Geleceği. Çev. Kaan H. Ökten. İstanbul: Everest Yayınları, 2003.

"Modernlik: Tamamlanmamış Bir Proje". Çev. Gülengül Naliş. Postmodernizm. Haz. Necmi Zekâ. 31-44. İstanbul: Kıyı Yayınları, 1994.

Heidegger, Martin. Varlık ve Zaman. Çev. Kaan H. Ökten. İstanbul: Agora Kitaplığı, 2008.

Kant, Immanuel. Ahlak Metafiziğinin Temellendirilmesi. Çev. İoanna Kuçuradi. Ankara: Türkiye Felsefe Kurumu, 2018.

Löwith, Karl. Tarihte Anlam. Çev. Caner Tura. İstanbul: Say Yayınları, 2012.

Nietzsche, Friedrich. Tarih Üzerine. Çev. Nejat Bozkurt. İstanbul: Say Yayınları, 2000.

Özlem, Doğan. Etik-Ahlak Felsefesi-. İstanbul: Say Yayınları, 2010.

"Evrenselcilik Mitosu ve Sosyal Bilimler". Sosyal Bilimleri Yeniden

Düşünmek Yeni Bir Kavrayışa Doğru. İstanbul: Metis Yayınları, 2001.

“ "Felsefi Hermenötiğe Geçiş Yolu Olarak Tarihselcilik". Ankara

Üniversitesi İlahiyat Fakültesi Dergisi 40/1 (1999): 127-145.

“Tarihsellik ve İnsan”. Felsefe Tartışmaları Dergisi 24 (1999): 7-21.

Tarih Felsefesi. İstanbul: Notos Kitap Yayınevi, 2000.

Ponzio, Augusto. "Levinas'ın Batı Düşüncesinin İki Kalesi Hümanizm ve Kimlik Üzerine Eleştirisi”. Çev. Hande Koçak. Monokl, 4/7-9 (Sonbahar 2010): 192- 208.

Ricoeur, Paul. Hafıza, Unutuş, Tarih. Çev. M. Emin Özcan. İstanbul: Metis Yayınları, 2010.

Yoruma Dair Freud ve Felsefe. Çev. Necmiye Alpay. İstanbul: Metis Yayınları, 2007.

Tatar, Burhanettin. "Ahlaki Hakikatin Zamansallığı”. Çağdaş Sorunlar Spekülatif Düşünceler. Samsun: Etüt Yayınları, 2008. 
Tarihle Etkileşimi Bağlamında Ahlaki Bilincin Evrenselliŏgi ve Tarihselliŏgi Problemi "Din ve Ahlâk İlişkisi". İslâm Ahlâk Esasları ve Felsefesi El Kitabı.

Ed. Müfit Selim Saruhan. Ankara: Grafiker Yayınları, 2016.

, Felsefi Hermenötik ve Yazarın Niyeti. Ankara: Vadi Yayınları, 1999.

Wachterhauser, Brice R. “Anlamada Tarih ve Dil”. Insan Bilimlerine Prolegomena. Der. \& Haz. Hüsamettin Arslan. İstanbul: Paradigma Yayınlar1, 2002. 